\title{
Allelopathic effects of jack bean leaf aqueous extract on safflower cultures
}

\section{Efectos alelopáticos del extracto acuoso de hojas de frijol canavalia sobre el cultivo de cártamo}

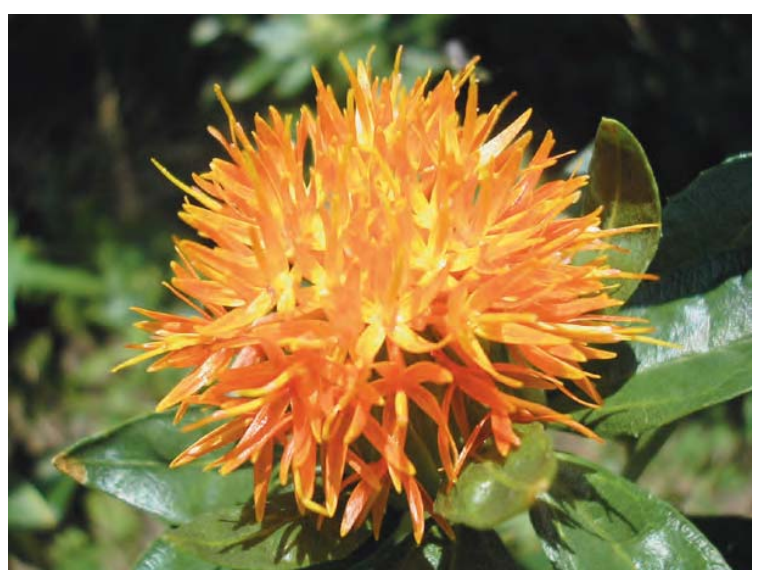

EDWARD SEABRA JÚNIOR'1, 2

DANIEL MARCOS DAL-POZZO'

ARMIN FEIDEN'

REGINALDO FERREIRA SANTOS ${ }^{1}$

LUCIENE KAZUE TOKURA'

Safflower inflorescence.

Photo: E. Seabra

\section{ABSTRACT}

This study verified the allelopathic influence of jack bean leaves (Canavalia ensiformis) on safflower cultures (Carthamus tinctorius), applied at different concentrations. Ten safflower genotypes were seeded in 20 containers, and a concentrate was prepared with jack bean leaves, crushed with water to make the extract. Five treatments were performed with four replicates, and this extract was applied at concentrations of $0 \%, 25 \%$, $50 \%, 75 \%$ and $100 \%$. The parameters were germination speed, percentage of germination, dry and fresh mass, leaf and root size. The jack beans influenced each evaluated treatment differently, presenting, at some times, neutral characteristics, inhibitory characteristics, or stimulating characteristics, varying according to the percentage of extract that was applied.

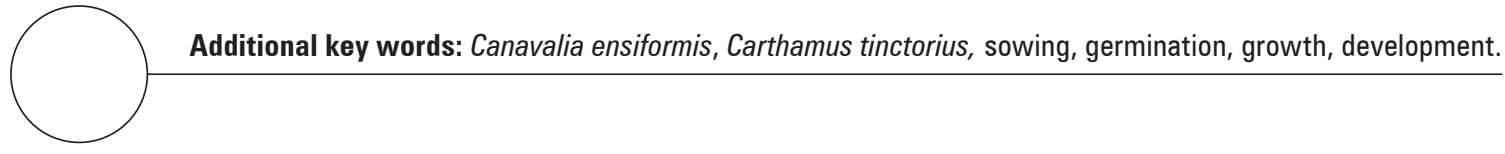

\section{RESUMEN}

Este estudio verificó la influencia alelopática del extracto de hojas del frijol canavalia (Canavalia ensiformis), sobre el cultivo de cártamo (Carthamus tinctorius) aplicado en diferentes concentraciones. Diez genotipos de cártamo fueron sembrados en 20 contenedores y la preparación del extracto acuoso fue a partir de la

\footnotetext{
Pós-Graduação em Engenharia de Energia na Agricultura (PPGEA), Western Paraná State University (UNIOESTE), Cascavel-PR, Brazil. ORCID Júnior, E.S.: 0000-0002-5562-6612; ORCID Dal-Pozzo, D.M.: 0000-0002-0995-0614; ORCID Feiden, A.: 0000-0001-8068-5422; ORCID Santos, R.F.: 0000-0002-7745-9173; ORCID Tokura, L.K.: 0000-0001-9758-0141

2 Corresponding author. seabra.edward@gmail.com
} 
maceración de hojas de frijol canavalia con agua. Se aplicaron cinco tratamientos (0, 25, 50, 75 e 100\%) del extracto de hoja con cuatro repeticiones. Se evaluaron los parámetros velocidad de germinación, porcentaje de germinación, masa seca y fresca, tamaño de hojas y raíces. Se encontró que el extracto acuoso de frijol canavalia influye de diferentes formas en los parámetros evaluados, presentando en algunos momentos características neutras, inhibitorias y estimulantes, variando de acuerdo al porcentaje del extracto aplicado.

Palabras clave adicionales: Canavalia ensiformis, Carthamus tinctorius, siembra, germinación, crecimiento, desarrollo.

Received for publication: 13-03-2017 Accepted for publication: 30-09-2017

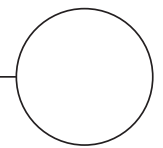



Molisch (1937) defined the concept of allelopathy, characterizing the biochemical interactions between plants (Rice, 1984). The term allelopathy is defined as any direct or indirect effect that a plant produces through the release of substances from secondary metabolism. These metabolites are capable of altering the germination potential or plant development. Compounds with allelopathic activity include tannins, glycosides, cyanogens, alkaloids, sesquiterpenes, flavonoids, and phenolic acids among others (Harper and Balke, 1981; King and Ambika, 2002).

Different plant organs, such as roots, leaves, flowers and fruits, can generate chemical substances. However, factors such as temperature, precipitation, and luminosity may cause changes in tissue concentration (Tur et al., 2010).

Allelopathic effects may inhibit the germination percentage and speed and reduce the initial growth of plants. The release of allelochemical compounds occurs through volatilization, leaching, residue decomposition and root exudates (Nery et al., 2013).

Allelopathic substances have been studied with the aim of minimizing applications of herbicides, insecticides and nematicides, which in the long term can lead to negative effects on the environment, human health and animal health (Stefanello, 2016).

The emergence and disappearance of plant species, as well as constant fluctuations in density and dominance of specific plants in cultivated ecosystems, such as pastures, have been attributed to different factors, such as the struggle for environmental components that are essential to survival (Putnam and
Tang, 1986). However, in the last three decades, several studies have noted that allelopathy plays a crucial role in the population of rural plants, changing vegetation pattern and density (Smith, 1989). Although Molisch's concept from (Molisch, 1937) involves both beneficial and malefic effects, the latter has occurred more than the former (Rice, 1984).

Allelopathy may also be used for pasture management through the selection of forage species, controlling undesirable pasture infestation by other plants through the allelopathic characteristics (Kato-Noguchi et al., 1994; Dudai et al., 1999). The consequence of this strategy includes a purer lineage, denser and with higher productivity, stimulating the longevity of crop production. This impact shows the unique ecological importance resulting from the possibility of providing alternative chemical structures, such as inputs in the production of agricultural defensive (Souza Filho and Alves, 1998).

According to Luckner (1990), Canavalia ensiformis, known as jack bean, belongs to the Fabaceae family, used as green cover; its root system is symbiotically associated with nitrogen-fixing bacteria and does not require the use of nitrogen fertilizers.

According to Corrêa (1974), the main C. ensiformis characteristic is its apparent rusticity and adaptive power to low fertility soils, causing immediate soil enriching, although it is not used much for pasture formation because it is not well accepted by animals.

Magalhães and Franco (1962) observed an inhibitory effect on the budding of sedge tubers (Cyperus rotundus), as well as chlorotic leaves when submitted to an 
aqueous extract of $C$. ensiformis root nodules. Anaya (1999) found that C. ensiformis leaves, when added to the soil, inhibited more than $50 \%$ of the incidence of root nematodes in tomato plants. The propagation of studies that seek to clarify the hypothesis of using this plant and its inhibitory effects to prevent the germination and growth of the radicle of weeds, as well as its main input as an allelopathic source, are needed to verify the true properties of this plant.

According to Santos et al. (2005), there is an allelopathic influence caused by applications of aqueous extracts obtained from C. ensiformis leaves on the initial seed germination of Senna obtusifolia, Mimosa pudica and Cassia occidentalis, which are undesirable plants in pastures. C. ensiformis has a strong inhibitory influence, and extracts obtained with solvents with higher dielectric constants were the most efficient at inhibiting the germination of tested seeds.

Mendonça (2008) determined the allelochemical substances of aqueous extracts of $C$. ensiformisvia HPLC and also evaluated the allelopathic influence on the germination of Ipomoea grandifolia and Commelinna benghalensis, with satisfactory results in relation to the inhibition of seed germination of undesirable plants.

In crop rotation, positive results were observed when rotating jack bean with maize and cowpea on coconut plantations, cultivated in altered lowland fertility soils in the Marajó Region, minimizing the damage caused to the soil by the traditional practice of successive monocultures, along with a reduction in the costs of maintenance and investment on coconut plantations (Rodrigues et al., 2004).

Another crop that is gaining prominence commercially is safflower (Cathamus tinctorius) because of the extraction of oil from its seeds (Khalid and Khan, 2017). Safflower is an oilseed grown for more than two thousand years; its final product is destined for the production of oil used in human food and in industrial uses. Its oil content can reach $50 \%$, presenting a high content of linoleic and oleic acid, considered great quality for human consumption and biodiesel production. The plant cycle is considerably short, lasting between 130 and 150 days (d). It is an option for late growing season production; however, the culture has received little attention in the Brazilian economic scenario (Gerhardt, 2012).
The safflower culture originated from the Mexican deserts, and has high resistance to low water and low relative humidity, and is therefore not sensitive to major climatic changes or soil droughts, and is available for cultivation in the summer or winter (Santos and Silva, 2015); in addition, the presence of thorns in its entire structure keeps away birds that may come to feed and could cause damage to several crops.

Thus, this study aimed to evaluate and characterize the allelopathic potential of jack beans applied at different concentrations to a safflower culture.

\section{MATERIAL AND METHODS}

This study was carried out in the greenhouse of the Western Paraná State University (UNIOESTE), from May $8^{\text {th }}$ to June $7^{\text {th }}, 2016$. UNIOESTE supplied the safflower seeds, which were sown in PVC tubes with a $100 \mathrm{~mm}$ diameter and $40 \mathrm{~cm}$ length.

The organic fertilizer came from the UNIOESTE compote. The fresh sedge leaves were collected for the aqueous extract preparation using $200 \mathrm{~g}$ leaves for $800 \mathrm{~mL}$ distilled water. The mixture was crushed in a Philco PH 900 Blender (Philco, São Paulo, Brasil) and stored in plastic container with aluminum foil wrap.

We used 20 containers; 10 genotypes of Carthamus tinctorius were sown in each one at a depth of $5 \mathrm{~cm}$. We studied five treatments (applied at different concentrations: Control $=0 \%$ concentration of extracts, $25 \%$ Extracts $=25 \%$ concentration of extracts, $50 \%$ Extracts $=50 \%$ concentration of extracts, $75 \%$ Extracts $=75 \%$ concentration of extracts and $100 \%$ Extracts $=100 \%$ concentration of extracts) with four replicates. Each treatment was irrigated with $500 \mathrm{~mL}$ of the respective extract concentrations. The irrigation was done every $3 \mathrm{~d}$, over a $30-\mathrm{d}$ period, applying the extract from the sowing of the seeds until the final date of observation. The analysis of the germination speed index of the plants (GSI) was done with Eq. 1, according to the Maguire (1962) methodology:

$$
I V G=\frac{E 1}{N 1}+\frac{E 2}{N 2}+\ldots \frac{E n}{N n}
$$

where $E_{1}$ and $E_{2}$ corresponded number of seedlings counted during the counting time; $N_{1}$ and $N_{2}$ corresponded number of sowing days. 
The genotype germination percentage $(G)$ was calculated using Eq. 2:

$$
\mathrm{G}=\frac{\mathrm{N}^{\circ} \text { de sementes germinadas }}{\text { total de sementes }} \times 100
$$

After the emergence of the plants, thinning was carried out so that only two plants per container remained, for a total of eight plants per treatment. For the plant evaluation, a trident Engineer's scale was used to measure the length of roots and leaves.

To evaluate the fresh leaf mass (FLM), the safflower leaves were weighed in a Shimadzu analytical balance (Shimadzu Co., Tokyo, Japan) with a precision of four decimal places. The leaves were then placed in Kraft paper packages and placed in a forced ventilation oven (Nova Ética, Vargem Grande Paulista, Brazil), at $70^{\circ} \mathrm{C}$ for approximately $72 \mathrm{~h}$. After drying, the plants were again weighed to obtain the dry leaf mass (DLM) data.

The experiment design was completely randomized with four replicates. The statistical analysis of the data was performed through analysis of variance and the comparison of means with the Tukey test at 5\% probability, as suggested by Beiguelman (2002), with Eqs. 3 and 4. The data were processed with the statistical programs Assistat 7.7 (Universidade Federal de Campina Grande, Brazil) and Excel Microsoft ${ }^{\circledR}$.

$$
\bar{x}=\frac{\sum_{i=1}^{n} x_{i}}{n}
$$

$$
\delta x=\sqrt{\frac{\sum_{i=1}^{n}\left(x_{i}-\bar{x}\right)^{2}}{n}}
$$

where $\delta X^{*}$ standard deviation; $\ddot{X}$ mean value; $X_{i}$ each sample value; $n$ total number of samples.

\section{RESULTS AND DISCUSSION}

Table 1 shows the values of germination percentage $(G)$, germination speed index (GSI), fresh leaf mass (FLM), dry leaf mass (DLM), leaf length (LL) and root length (RL) of the safflower plant genotypes in the germination and initial development stage of the plants, with and without the application of aqueous extracts of jack bean leaves.

In table 1 , only the $50 \%$ Extracts treatment $75 \%$ initial germination $(G)$ showed a significant inhibitory effect in the development. For the germination speed index (GSI), no significant effect was identified as a function of the variation of the treatments. The results are close to the ones found by Costa and Zimmermann (1988), when stating that according to environmental conditions, some production components may increase or decrease.

For leaf length (LL), a negative interaction was observed from tests 25\%Etracts, 50\%Etracts and $100 \%$ Etracts; however, in $75 \%$ Etracts, this behavior was not identified in this parameter. For root length (RL), the data did not present a significant effect in any of the evaluated treatments. Freitas (2004)

Table 1. Mean values of germination percentage (G), germination speed index (GSI), leaf length (LL) and root length (RL) with and without application of extracts concentration of jack bean leaves on safflower cultures.

\begin{tabular}{|l|c|c|c|c|}
\hline \multicolumn{1}{|c|}{ Treatments } & $\begin{array}{c}\text { G } \\
(\%)\end{array}$ & $\begin{array}{c}\text { GSI } \\
(\%)\end{array}$ & $\begin{array}{c}\text { LL } \\
(\mathrm{cm})\end{array}$ & $\begin{array}{c}\text { RL } \\
(\mathrm{cm})\end{array}$ \\
\hline Control & $8.75 \mathrm{~b}$ & $2.81 \mathrm{a}$ & $23.16 \mathrm{a}$ & $11.19 \mathrm{a}$ \\
\hline 25\%Extracts & $5.25 \mathrm{~b}$ & $2.54 \mathrm{a}$ & $18.50 \mathrm{~b}$ & $8.830 \mathrm{a}$ \\
\hline $50 \%$ Extracts & $4.00 \mathrm{~b}$ & $1.55 \mathrm{a}$ & $18.91 \mathrm{~b}$ & $11.75 \mathrm{a}$ \\
\hline $75 \%$ Extracts & $32.5 \mathrm{a}$ & $1.70 \mathrm{a}$ & $22.83 \mathrm{a}$ & $14.10 \mathrm{a}$ \\
\hline $100 \%$ Extracts & $3.00 \mathrm{~b}$ & $2.25 \mathrm{a}$ & $22.25 \mathrm{ab}$ & $12.33 \mathrm{a}$ \\
\hline General mean & 10.7 & 2.17 & 21.13 & 11.78 \\
\hline DMS & 13.02 & 1.9 & 3.86 & 5.57 \\
\hline CV (\%) & 55.68 & 40.09 & 10.78 & 27.86 \\
\hline P & $<0.0001$ & 0.2475 & 0.0018 & 0.1266 \\
\hline F & 17.26 & 1.5162 & 5.81 & 1.99 \\
\hline
\end{tabular}

Means followed by the same letter do not differ statistically from each other according to the Tukey test $(P \leq 0.05)$ 
observed similar results, in which sedge (Cyperus rotundus) plants were submitted to the same treatment, but no expressive allelopathic effect of the extracts was identified.

There was an inhibitory action between the increase of $C$. ensiformis extract concentration in the dry mass (DLM) and fresh leaf (FLM) parameters of the safflower when compared to the control treatment. The behaviors were linearly aligned as shown in figure 1 and 2 .

For fresh leaf mass, figure 1 shows that the development underwent considerable inhibition from $25 \%$ Extracts $=5.46 \mathrm{~g}$. In treatment $50 \%$ Etracts $=$

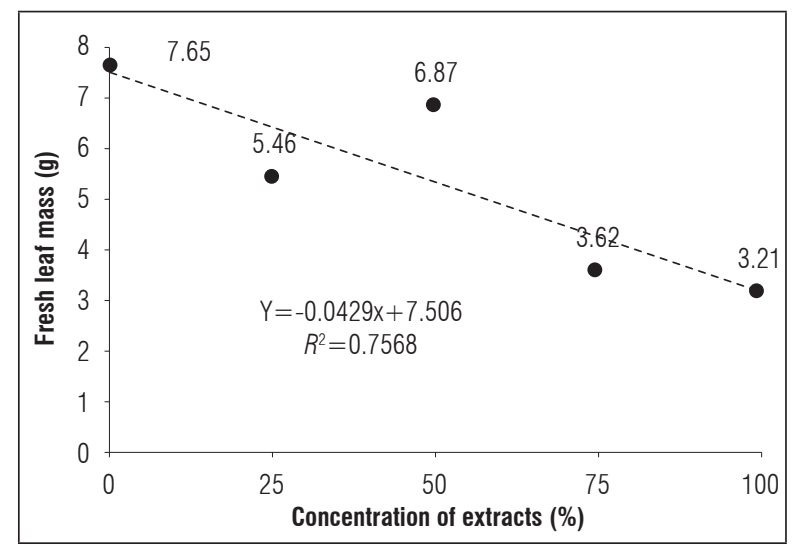

Figure 1. Variation of fresh leaf mass (FLM) as a function of jack bean leaf extract concentration on safflower cultures.

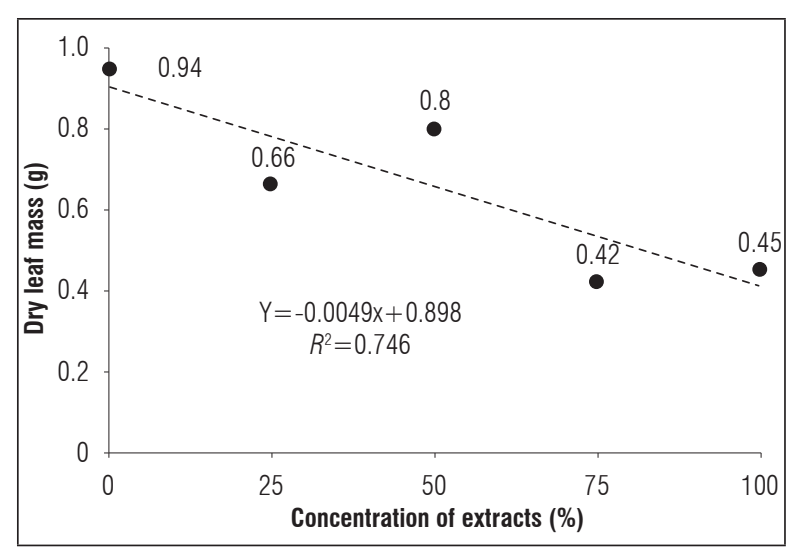

Figure 2. Variation of dry leaf mass (DLM) as a function of jack bean leaf extract concentration on safflower cultures.
$6.87 \mathrm{~g}$, a stimulating effect occurred when compared to $25 \%$ Etracts although the value of the control treatment $=7.65 \mathrm{~g}$ was not exceeded. The 50\%Etracts and $75 \%$ Etracts treatments also had values that were lower than the control treatment, representing 3.62 and $3.21 \mathrm{~g}$, respectively.

For the dry leaf mass, figure 2 shows a decrease in the development of the plants, as a result of the increase in the concentration of the extract from $25 \%$ Extracts $=0.66 \mathrm{~g}$. As seen in the fresh leaf mass, $50 \%$ Etracts $=0.8 \mathrm{~g}$ had a stimulating effect although this value did not exceed the value of the control treatment $=0.94 \mathrm{~g} .75 \%$ Etracts and $100 \%$ Etracts treatments also presented lower values when compared to the control treatment, presenting 0.42 and $0.45 \mathrm{~g}$, respectively.

The results are similar to those of Rice (1984), meaning the variation in extract concentration may present different results, both inhibitory and stimulating results in certain cases. Similarly, allelopathic effects on leaf length were reported by Magalhães and Franco (1962), who tested extracts of the aerial part of the jack bean in the control of nutsedge (Cyperus rotundus), verifying detrimental effects on top growth. The experiments showed that, depending on the evaluated parameters, extracts of jack bean leaves applied to safflower cultures can present inhibitory characteristics or stimulating actions, affecting the development indicators of plants differently.

\section{CONCLUSIONS}

Based on the results, it is possible to conclude that the application of aqueous extracts of jack bean leaves exerts an allelopathic influence on the germination and development of safflower cultures in different ways.

The initial germination (G) decreased as a result of the increase of the concentration of the extract for the treatments with 25\% Extracts, 50\%Extracts and $100 \%$ Extracts of the extract although the application of the extract at $75 \%$ Extracts favored germination, which indicates that safflower can react differently to extracts of jack beans. However, for the parameters germination speed index (GSI), root length (RL) and leaf length (LL), at inhibitory action was identified at some times; however, the application of the extract did not have an influence at other times. 
Finally, the inhibitory action of the extract of jack bean leaves on safflower cultures was confirmed by the tendency for a reduction in the weight of the leaf dry mass (DLM) and leaf fresh mass (FLM), as compared with the control test, which directly decreased with the increase of the extract concentration.

Conflict of interests: the manuscript was prepared and reviewed with the participation of the authors, who declare that there exists no conflict of interest that puts in risk the validity of the presented results.

\section{BIBLIOGRAPHIC REFERENCES}

Anaya, A.L. 1999. Allelopathy as a tool in the management of biotic resource in agroecosystems. Crit. Rev. Plant Sci. 18(6), 697-738. Doi: 10.1080/07352689991309450

Beiguelman, B. 2002. Curso prático de bioestatística. $5^{\mathrm{a}} \mathrm{ed}$. FUNPEC Editora, Ribeirão Preto, Brazil.

Corrêa, M.P. 1974. Dicionário das plantas úteis do Brasil e exóticas cultivadas. Ministério da Agricultura, Rio de Janeiro, Brazil.

Costa, J.C.G. and M.J.O. Zimmermann. 1998. Melhoramento genético. pp. 229-245. In: Zimmermann, M. J.O., M. Rocha, and T.E.U. Yamada (eds.). A cultura do feijoeiro: fatores que afetam a produtividade. Potafós, Piracicaba, Brazil.

Dudai, N., A. Poljakoff-Mayber, A.M. Mayer, E. Putievsky, and H.R. Lerner. 1999. Essencial oils as allelochemicals and their potential use as bioherbicides. J. Chem. Ecol. 25(5) 1079-1089. Doi. 10.1023/A:1020881825669

Freitas, M.C. 2004. Efeito alelopático de leguminosas como adubos verdes sobre a germinação e emergência de plantas daninhas. Trabalho de conclusão de curso. Unicastelo, Fernandópolis, Brazil.

Gerhardt, I.F.S. 2012. Devergência genética entre acessos de cártamo. Botucatu 1, 1-35.

Harper, J.R. and N.E. Balke. 1981. Characterization of the inhibition of $\mathrm{k}^{+}$absorption in oat roots by salicylic acid. Plant Physiol. 8(6), 1349-1353. Doi: 10.1104/ pp.68.6.1349

Kato-Noguchi, H., S. Kosemura, S. Yamamura, J. Mizutani, and K. Hasegawa. 1994. Allelopathy of oats. I. Assessment of allelopathic potential of extract of oat shoots and identification of an allelochemical. J. Chem. Ecol. 20(2), 309-314. Doi: 10.1007/BF02064439

Khalid, N. and R.S. Khan. 2017. A comprehensive characterization of safflower oil for its potential applications. Trends Food Sci. Technol. 66, 176-186. Doi: 10.1016/j. tifs.2017.06.009

King, S.R. and R. Ambika. 2002. Allelopathic plants. 5. Chromolaen odorata (L.). Allelopath. J. 9(1), 35-41.
Luckner, M. 1990. Secondary metabolism in microorganisms, plants, and animals. Gustav Fischer Verlag, Jena, Germany. Doi: 10.1007/978-3-662-09838-7

Magalhães, A.C. and C.M. Franco. 1962. Toxicidade do feijão-de-porco sobre tiririca. Bragantia 21, 53-57. Doi: 10.1590/S0006-87051962000100064

Maguire, J.D. 1962. Speeds of germination-aid selection and evaluation for seedling emergence and vigor. Crop Sci. 2, 176-177. Doi: 10.2135/ cropsci1962.0011183X000200020033x

Mendonça, R. 2008. Lourenço de determinação de aleloquímicos por HPLC/UV-Vis em extratos aquosos de sementes de Canavalia ensiformes e estudo da atividade alelopática. M.Sc thesis. Instituto de Química de São Carlos, Universidade de São Paulo, São Carlos, Brazil.

Molisch, H. 1937. Der Einfluss einer Pflanze auf die andere Allelopathie. Gustav Fischer Verlag, Jena, Germany.

Nery, M.C., M.L.M. Carvalho, F.C. Nery, and R.M.O. Pires. 2013. Potencial alelopático de Raphanus sativus L. var. oleiferus. Abrates 23(1), 15-19.

Putnam, A.R. and C. Tang. 1986. The science of allelopathy. Wiley, New York, USA

Rice, E.L. 1984. Allelopathy. $2^{\text {th }}$ ed. Academic Press, New York, USA.

Rodrigues, J.E.L.F., R.N.B. Alves, O.M.N. Lopes, R.N.G. Teixeira, and E.S. Rosa. 2004. A Importância do feijão-de-porco (Canavalia ensiformis DC) como cultura intercalar em rotação com milho e feijão caupi em cultivo de coqueirais no município de Ponta-de-Pedras/ Marajó-PA. Technical statement No. 96. Embrapa Amazônia Oriental, Brasília, Brazil.

Santos, S., M.L.L. Moraes, A.P.S. Souza Filho, and M.O.O. Rezende. 2005. Allelopathic potential and systematic evaluation of organic extracts from Canavalia ensiformis leaves (Jack beans). J. Environ. Sci. Health B 40(1), 77-84. Doi: 10.1081/PFC-200034234

Santos, R.F. and M.A. Silva. 2015. Carthamus tinctorius L.: Uma alternativa de cultivo para o Brasil. Acta Iguazu 4(1), 26-35.

Souza Filho, A.P.S. and S.M. Alves. 1998. Alelopatia em ecossistemas de pastagens cultivadas. Documents No. 109. Embrapa-Cpatu, Belém, Brazil.

Smith, A.E. 1989. The potential allelopathic characteristics of bitter sneezeweed (Helenium amarum). Weed Sci. 37(5) 665-669.

Stefanello, R., L.A.S. Neves, M.A.B. Abbad, and B.B. Vianna. 2016. Potencial alelopático de extratos de chia na germinação e no vigor de sementes de rabanete. Rev. Cultiv. Saber 9(1), 11-23.

Tur, C.M., J. Borella, and L.H. Pastorini. 2010. Alelopatia de extratos aquosos de Duranta Repens sobre a germinação e o crescimento inicial de Lactuca sativa e Lycopersicum esculentum. Biotemas 23(2), 13-22. 